\title{
Potentially mobile of heavy metals on the surface sediments in tropical hyper-saline and positive estuaries
}

\author{
CARLOS A. RAMOS E SILVA ${ }^{1,3,4}$, ESTEFAN M. DA FONSECA ${ }^{1}$, BEATRIZ W. \\ GROTTO $^{1}$, FLAVO E.S. DE SOUZA ${ }^{2}$ and JOSÉ A. BAPTISTA NETO ${ }^{1}$ \\ ${ }^{1}$ Postgraduate Program in Dynamics of Oceans and Earth, Fluminense Federal University, Av. Gen. Milton \\ Tavares de Souza, s/n, Gragoatá, Campus da Praia Vermelha, 24210-346 Niterói, RJ, Brazil \\ ${ }^{2}$ Agricultural School of Jundiaí, Federal University of Rio Grande do Norte, RN \\ 160, Km 03, Jundiaí District, 59280-000 Macaíba, RN, Brazil \\ ${ }^{3}$ Department of Oceanography and Limnology, Rio Grande do Norte Federal University, \\ Av. Sen. Dinarte Mariz, s/n, Mãe Luíza, 59075-970 Natal, RN, Brazil \\ ${ }^{4}$ Center for Study of Water, Biomass and Oil (NAB), Fluminense Federal University, Av. Gen. Milton \\ Tavares de Souza, s/n, Gragoatá, Campus da Praia Vermelha, 24210-346 Niterói, RJ, Brazil \\ Manuscript received on February 20, 2017; accepted for publication on September 30, 2017
}

\begin{abstract}
Estuarine sediments represent important pools of trace metals, released from both anthropogenic and natural sources. Fluctuations in the water column physicochemical conditions, on the other hand, may transfer metals from solid to liquid compartment and resulting in contamination of the surrounding environment. The present research was carried out to evaluate the weakly bounded heavy metal levels in tropical hypersaline and positive estuaries, in order to quantify its potentially availability. The monitoring includes five metals $(\mathrm{Cd}, \mathrm{Cr}, \mathrm{Cu}, \mathrm{Pb}, \mathrm{Zn})$ and cover nine estuaries in Rio Grande do Norte state/Brazil, including four hypersaline and five true estuaries. 50 surface sediment samples were collected in each estuary. At the same time, organic matter concentrations were evaluated in order to help explaining possible local variations in heavy metal levels. Organic matter results $(0.7 \%-7.3 \%)$ suggest the positive Potengi estuary as the most critical environmental quality situation. On the other hand, according to heavy metals levels, both Conchas and Potengi estuaries registered the higher concentrations of $\mathrm{Cr}$. The highest concentrations were observed in the hyper-saline estuaries, with the exception of the $\mathrm{Zn}$. The present study revealed that the watershed occupation has significantly influenced the heavy metal concentrations in the estuaries.
\end{abstract}

Key words: weakly bounded heavy metal, hyper-saline waters, positive estuaries, surface sediment.

\section{INTRODUCTION}

Available contaminant in water-bodies can result in negative impacts to marine environment, which above critic concentrations can impact

Correspondence to: Carlos Augusto Ramos e Silva

E-mail: caugusto_99@yahoo.com biota communities (Singh et al. 2011) and dietary restrictions on seafood production (Hosseini et al. 2013). Regardless of the source, contaminants such as heavy metals are immediately scavenged by floating particles in the water column and are concentrated in hydrodynamically calm water basins where fine sediments accumulate. Thus, 
sheltered estuaries tend to be particularly sensible to contaminated loads (Vaalgamaa 2004).

Heavy metals are one of the most usual pollutants in water ecosystems and may have its sources from natural and anthropogenic origins, such as industrial, agricultural and domestic loads (Hang et al. 2009, Ramos e Silva et al. 2006, Davutluoglu et al. 2011). When released in aquatic environment, these metals tend to accumulate in the sub aquatic bottoms, where sediments have high deposition capacity and further potential to liberate these contaminants (Salomons and Stigliani 1995, Passos et al. 2011). This return into the overlying water column layer may be resulted from variations in water physicochemical features such as $\mathrm{pH}$, redox potential and oxygen concentrations (Förstner and Kersten 1989, Davutluoglu et al. 2011). Nevertheless, the bottom particles act as sinks of metals, representing a record of the pollution chronology of the environment (Hang et al. 2009, Davutluoglu et al. 2011).

Total concentrations of heavy metal study in sediments is not considered an effective indicator when the goal is the evaluation between natural and anthropogenic sources (Relic et al. 2010, Passos et al. 2011, Okoro et al. 2012) and its potential availability (Zhong et al. 2011). Therefore, recent researches have applied partial extraction approaches to analyze the specific chemical forms with sedimentary phases and metal sources (Hang et al. 2009, Davutluoglu et al. 2011).

Surveys on heavy metal contamination, especially in coastal areas, have improved over the last decades around the world. In recent time, the use of innovative artificial mussel (AM) technology has been used to monitor heavy metals in the Oceans, coastal areas, estuaries, rivers in different countries in the world (Kibria et al. 2012, 2016). However, in tropical and subtropical regions such as Brazil and other South American countries, only limited information about this matter is available, mainly in estuarine areas where, added to natural inputs, concomitant anthropogenic activities such as port activities, together with industrial, agricultural and residential activities around the water body can provide pollutants, especially heavy metals, to the environment.

The evaluation of heavy metal contaminants in semi-enclosed water bodies like estuaries is a complex process influenced by physical and chemical variables.

Nowadays the coastal environments of the northeast shore of Rio Grande do Norte state are passing through a strong anthropogenic stress, such as: mainly oil exploration, salt production and marine shrimp culture expansion (Costa et al. 2015). Particularly, shrimp farming affects the environment primarily through the discharge of harmful effluents (fertilizers and other chemicals) and mangrove deforestation (Ramos Silva et al. 2010).

The main objective of the present study are to understand the distribution of the potentially available heavy metals in estuarine sediments in tropical hyper-saline and positive estuaries.

\section{MATERIALS AND METHODS}

Nine estuaries in Rio Grande do Norte (RN), Northeastern Brazil, were studied. Four of these, Apodi, Guamaré, Galinhos and Conchas (Figure $1)$, are classified as hyper-saline estuaries, that is, estuaries that experience low inflow at times, and are located in a more arid region of Northern RN. The other five systems, Ceará-Mirim, Potengi and Nísia-Floresta, Papeba and Guaraíra estuaries (Figure 2), are positive estuaries located in the eastern region of the state, where most domestic effluents are released (Ramos e Silva et al. 2006).

Fifty surface sediment samples were collected with a Van Veen grab in each estuary, totalizing 450 samples. The material collected was stored in plastic bags, cooled to $4^{\circ} \mathrm{C}$ and sent to the laboratory, where the fraction with particle size 


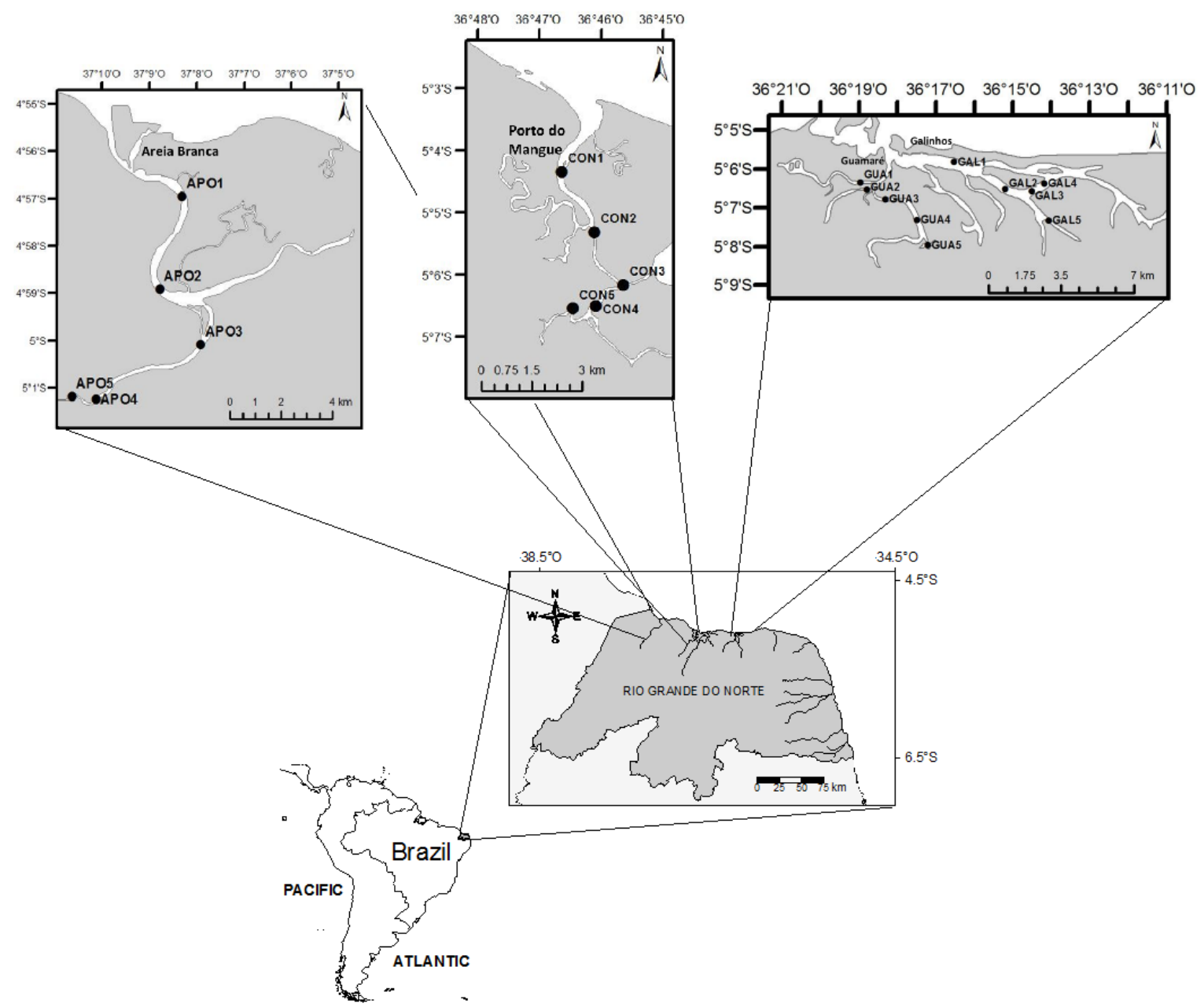

Figure 1 - Study Area (APO - Apodi sampling station / CON - Conchas sampling station / GUA - Guamaré sampling station / GAL - Galinhos sampling stations).

$<1 \mathrm{~mm}$ was separated by sieving. To evaluate the potentially mobile metals, cold acid extraction procedures were used, in order to simulate the natural mobilization processes of these more "labile" elements of the sediments (Bevilacqua et al. 2009). The extraction procedure with $0.5 \mathrm{~mol} / \mathrm{L}$ diluted hydrochloric acid $(\mathrm{HCl})$ was applied (Sutherland and Tack 2008, Bevilacqua et al. 2009, Li et al. 2009). The procedure is based on the extraction of $0.5 \mathrm{~g}$ of sample with $10 \mathrm{~mL}$ of a solution of $0.5 \mathrm{~mol} / \mathrm{L} \mathrm{HCl}$ under continuous stirring at $200 \mathrm{rpm}$ for $1 \mathrm{~h}$ at $20^{\circ} \mathrm{C}$. The suspended material obtained was filtered through cellulose ester filter of $0.20 \mathrm{~mm}$ porosity prior to quantification of
$\mathrm{Cu}, \mathrm{Cr}, \mathrm{Ni}, \mathrm{Pb}$, and $\mathrm{Zn}$, certified for the reference material BCR-701. The quantification of metallic cations in solution was performed in an ICP-OES at the Agricultural School of Jundiaí, in Federal University of Rio Grande do Norte.

At the same time, organic matter concentrations were evaluated in order to explain possible local variations in heavy metal levels.Organic matter content in the sediments was determined by the calcination technique according to Byers et al. (1978).

Obtaining the volume and the area of the channels of the Potengi, Nísia-Floresta, Papeba and Guarairas estuaries took into account the 


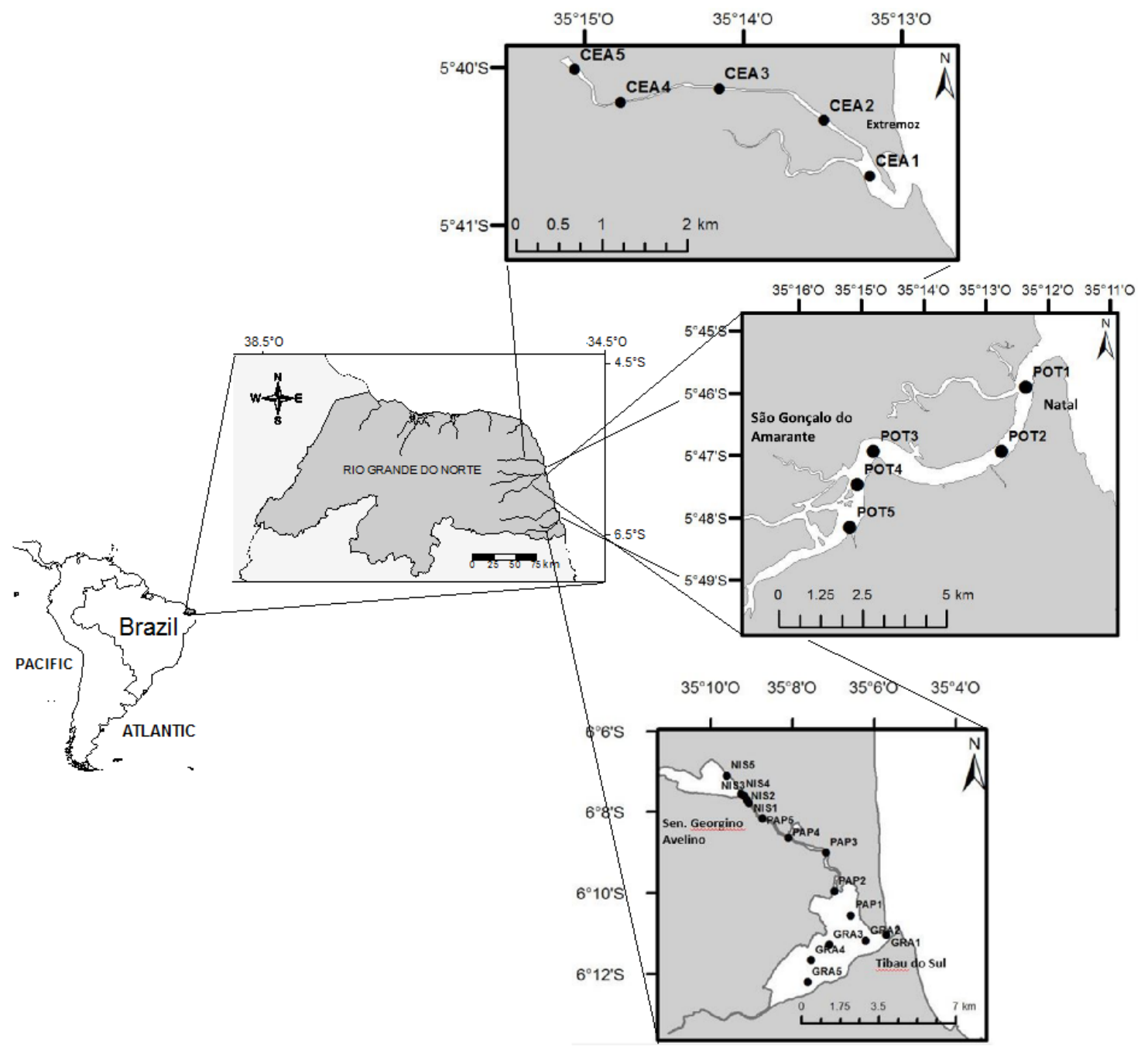

Figure 2 - Study area ( CEA - Ceara Mirim sampling stations / POT - Potengi sampling stations / NIS - Nísia-Floresta sampling stations / PAP - Papeba sampling stations / GRA - Guaraíra sampling stations.

bathymetric data regarding field surveys using an eco-sound. The depths were corrected according to the tide variation, obtaining the pairs of coordinates and the depths of each point $(x, y, z)$. For this, the Surfer v.7.0 program (continuous surface modeling) was used, where the margins of each estuary were digitized to delimit the channels. The isotropic method of kriging was used for the calculation of volume and area.

The areas and volumes of the Apodi, Conchas, Guamaré, Galinhos, and Ceará-Mirim estuaries were obtained from the sum of the sampling areas (Figures 1 and 2), digitized on the official topographical charts and multiplied by the depth obtained in Field at the moment of sample collection in quadrature cycles. That is, with little variation of depth. This was intended to have a better approximation of the volume.

The areas and volumes allowed to obtain the dilution capacity of each estuary (Table II).

The Kruskal-Wallis variance test was performed to identify statistically significant differences $(\mathrm{p}<0.05)$ between negative and positive estuaries, based on heavy metal and organic matter concentrations. Lastly, correlations between the analyzed parameters were made by applying 
Spearman's test. The probability of 0.05 or less was considered significant.

\section{RESULTS AND DISCUSSION}

Extraction of metals with $0.5 \mathrm{M} \mathrm{HCl}$ is effective in the dissolution of complex formation, adsorbed and precipitated metals in the sediment without attacking the silicate. Agemian and Chau (1976) observed that the average amount of silicon extracted with the $0.5 \mathrm{M} \mathrm{HCl}$ method corresponds to $1 \%$ of the total concentration. Moalla (1997) compared the extraction technique with $0.5 \mathrm{M} \mathrm{HCl}$ with other more conventional techniques using ammonium oxalate and royal water and confirmed that the former is a reliable, fast, harmless, simple and inexpensive method for measuring concentrations of potentially available or anthropogenic metals in aquatic sediments.

According to Sindern et al. (2007), human presence can be verified by heavy metal levels exceeding the range of background concentrations. The hyper-saline Apodi and Conchas estuaries had the highest concentrations for $\mathrm{Cr}, \mathrm{Cu}, \mathrm{Cd}$ and $\mathrm{Pb}$, respectively $(3.2 \mu \mathrm{g} / \mathrm{g}, 5.1 \mu \mathrm{g} / \mathrm{g}, 0.5 \mu \mathrm{g} / \mathrm{g} ; 21.4$ $\mu \mathrm{g} / \mathrm{g})$. On the other hand, positive Nísia-Floresta estuary had the highest concentration for $\mathrm{Zn}$ (7.6 $\mu \mathrm{g} / \mathrm{g}$ ). The reason for the observed geographical variation in the availabilities of the metals is most probably the input of these metals in dissolved and/ or particulate form through anthropogenic activities (Ramos e Silva et al. 2003). The nine estuaries systems are under different human activities, such as: agriculture, shrimp farm, domestic sewage, husbandry and soil drilling activities (Ramos e Silva et al. 2003, Lacerda et al. 2006). These activities are potential sources of metals $(\mathrm{Cr}, \mathrm{Cu}, \mathrm{Cd}, \mathrm{Pb}$ and $\mathrm{Zn}$ ) to the estuaries. Added to these the hypersaline estuaries are under high mean evaporation of approximately 2,600 mm/yr (Ramos e Silva et al. 2006). Among the hyper-saline estuaries, Guamare showed the lowest concentrations for all metals (Table I). This scenario may be explained by its high dilution capacity (area to volume ratio $=$ $0.42 \mathrm{~m}^{2} / \mathrm{m}^{3}$; Table II). On the other hand, the high concentrations of $\mathrm{Zn}$ in Nízia-Floresta positive estuary can be explained by its lower dilution capacity (area to volume ratio $=0.95 \mathrm{~m}^{2} / \mathrm{m}^{3}$; Table II, besides the anthropogenic activities already mentioned. Our ratio values between area and volume $\left(\mathrm{m}^{2} / \mathrm{m}^{3}\right)$ to Apodi, Guamaré, Ceará-Mirin and Guaraíra estuaries are an order of magnitude below the values recorded by Lacerda et al. (2006). These authors considered the entire basin area to discuss the dilution of loads within the channel of each estuary.

As mentioned above Conchas estuary revealed higher potentially mobile Cr levels among all studied estuaries (Table I). It is well known that possible sources of $\mathrm{Cr}$ include leather manufacturing (Földi et al. 2013, Kumar et al. 2014), being the tanning method the most utilized for a century (Mutlu et al. 2014). So, Testa et al. (2004) confirmed the leather tanning is a significant activity present in the Piranhas-Açu watershed.

Nowadays, the estuarine region of Galinhos presents soil occupation problems with irregular open dumps zones installed (Diniz et al. 2015). Additionally, the area represents its mangrove ecosystem impacted with the growing of shrimp farms. Lastly, the local marine tourism represents an important activity, with potential environmental impacts (Diniz et al. 2015).

The Ceará-Mirim estuarine area and the Papeba and Guaraíra estuaries registered the smaller concentrations of all the analyzed metals (Table I). The coastal region of Ceará-Mirim presents some environmental protection areas. Nevertheless, no heavy metal enrichment pattern was registered. $\mathrm{Cr}, \mathrm{Cd}$ and $\mathrm{Pb}$ presented minimum concentrations in the Nísia-Floresta estuary, however $\mathrm{Cu}$ and $\mathrm{Zn}$ showed the higher concentration of all estuaries studied. These three positive estuaries are inserted in an environmental protection area. 
TABLE I

Metal concentrations in the estuaries of Rio Grande do Norte and reference data in sediments of different systems around the world (average values in $\mu \mathrm{g} / \mathrm{g}$ ).

\begin{tabular}{|c|c|c|c|c|c|c|c|c|}
\hline Estuaries & Method & $\begin{array}{c}\text { Sediment } \\
\text { fraction }\end{array}$ & $\mathrm{Cr}$ & $\mathrm{Cu}$ & Cd & $\mathbf{P b}$ & $\mathbf{Z n}$ & References \\
\hline $\begin{array}{l}\text { Apodi } \\
\text { estuary }\end{array}$ & $\begin{array}{l}0.5 \mathrm{M} \mathrm{HCl} \\
\text { extraction }\end{array}$ & $<1 \mathrm{~mm}$ & 3.2 & 2.3 & 0.5 & 21.4 & 5.4 & This study \\
\hline $\begin{array}{l}\text { Conchas } \\
\text { estuary }\end{array}$ & $\begin{array}{l}0.5 \mathrm{M} \mathrm{HCl} \\
\text { extraction }\end{array}$ & $<1 \mathrm{~mm}$ & 7.0 & 5.1 & $<0.4$ & 17.1 & 6.0 & This study \\
\hline $\begin{array}{l}\text { Guamaré } \\
\text { estuary }\end{array}$ & $\begin{array}{l}0.5 \mathrm{M} \mathrm{HCl} \\
\text { extraction }\end{array}$ & $<1 \mathrm{~mm}$ & 3.2 & 0.5 & $<0.4$ & 6.4 & 1.6 & This study \\
\hline $\begin{array}{l}\text { Galinhos } \\
\text { estuary }\end{array}$ & $\begin{array}{l}0.5 \mathrm{M} \mathrm{HCl} \\
\text { extraction }\end{array}$ & $<1 \mathrm{~mm}$ & 3.8 & 1.2 & $<0.4$ & 18.6 & 4.1 & This study \\
\hline $\begin{array}{l}\text { Ceará-Mirim } \\
\text { estuary }\end{array}$ & $\begin{array}{l}0.5 \mathrm{M} \mathrm{HCl} \\
\text { extraction }\end{array}$ & $<1 \mathrm{~mm}$ & $<0.4$ & $<0.4$ & $<0.4$ & $<0.4$ & 0.1 & This study \\
\hline $\begin{array}{l}\text { Potengi } \\
\text { estuary }\end{array}$ & $\begin{array}{l}0.5 \mathrm{M} \mathrm{HCl} \\
\text { extraction }\end{array}$ & $<1 \mathrm{~mm}$ & 4.8 & 3.2 & $<0.4$ & 9.5 & 6.9 & This study \\
\hline $\begin{array}{l}\text { Nísia- } \\
\text { Floresta } \\
\text { estuary }\end{array}$ & $\begin{array}{l}0.5 \mathrm{M} \mathrm{HCl} \\
\text { extraction }\end{array}$ & $<1 \mathrm{~mm}$ & $<0.4$ & 5.1 & $<0.4$ & $<0.4$ & 7.6 & This study \\
\hline $\begin{array}{l}\text { Papeba } \\
\text { estuary }\end{array}$ & $\begin{array}{l}0.5 \mathrm{M} \mathrm{HCl} \\
\text { extraction }\end{array}$ & $<1 \mathrm{~mm}$ & $<0.4$ & $<0.4$ & $<0.4$ & $<0.4$ & 1.1 & This study \\
\hline $\begin{array}{c}\text { Guaraíra } \\
\text { estuary }\end{array}$ & $\begin{array}{l}0.5 \mathrm{M} \mathrm{HCl} \\
\text { extraction }\end{array}$ & $<1 \mathrm{~mm}$ & $<0.4$ & $<0.4$ & $<0.4$ & $<0.4$ & $<0.4$ & This study \\
\hline $\begin{array}{c}\text { Sinos estuary, } \\
\text { Brazil }\end{array}$ & $\begin{array}{l}0.5 \mathrm{M} \mathrm{HCl} \\
\text { extraction }\end{array}$ & $<63 \mu \mathrm{m}$ & 20.7 & 45.4 & - & 12.7 & 83.9 & Schneider et al. 2014 \\
\hline $\begin{array}{c}\text { Lake Karla, } \\
\text { Greece }\end{array}$ & $\begin{array}{l}0.5 \mathrm{M} \mathrm{HCl} \\
\text { extraction }\end{array}$ & $<63 \mu \mathrm{m}$ & 298.3 & 38.2 & - & 34.3 & 2.2 & Skordas et al. 2015 \\
\hline $\begin{array}{c}\text { Laurel Creek, } \\
\text { Canada }\end{array}$ & $\begin{array}{l}0.5 \mathrm{M} \mathrm{HCl} \\
\text { extraction }\end{array}$ & $<63 \mu \mathrm{m}$ & 8.6 & 48.6 & 2.2 & 58.5 & - & Kominar 2002 \\
\hline $\begin{array}{c}\text { Manoa } \\
\text { watershed, } \\
\text { USA }\end{array}$ & $\begin{array}{l}0.5 \mathrm{M} \mathrm{HCl} \\
\text { extraction }\end{array}$ & $<125 \mu \mathrm{m}$ & - & 52.0 & - & 41.0 & 142 & Sutherland 2002 \\
\hline $\begin{array}{c}\text { Suape } \\
\text { Harbor, } \\
\text { Brazil }\end{array}$ & $\begin{array}{l}0.1 \mathrm{M} \mathrm{HCl} \\
\text { extraction }\end{array}$ & $<53 \mu \mathrm{m}$ & 1.82 & 5.1 & 0.4 & 3.6 & 13.7 & Téodulo et al. 2003 \\
\hline $\begin{array}{l}\text { Poxim } \\
\text { estuary, } \\
\text { Brazil }\end{array}$ & $\begin{array}{l}\text { BCR Sequencial } \\
\text { extraction }\end{array}$ & - & 3.5 & 5.7 & 0.2 & 9.0 & 12.4 & Passos et al. 2010 \\
\hline $\begin{array}{l}\text { Mahanadi } \\
\text { River basin, } \\
\text { India }\end{array}$ & $\begin{array}{c}\text { Sequencial } \\
\text { extraction } \\
\text { (Tessier) }\end{array}$ & $<88 \mu \mathrm{m}$ & 3.1 & 4.0 & 1.4 & 7.9 & 20.0 & Sundaray et al. 2011 \\
\hline $\begin{array}{l}\text { Pearl estuary, } \\
\text { China }\end{array}$ & $\begin{array}{l}\text { Simultaneous } \\
\text { extraction }\end{array}$ & - & - & 16.7 & 4.1 & 32.5 & 52.6 & Fang et al. 2005 \\
\hline
\end{tabular}


TABLE II

Major environmental characteristics of the nine estuaries studied along the coast of Rio Grande do Norte, NE Brazil.

\begin{tabular}{|c|c|c|c|}
\hline $\begin{array}{l}\text { Classification/ } \\
\text { Estuary }\end{array}$ & $\begin{array}{c}\text { Lower } \\
\text { basin area } \\
\left(\mathrm{km}^{2}\right)\end{array}$ & $\begin{array}{c}\text { Estuarine } \\
\text { volume } \\
\left(10^{3} \mathrm{~m}^{3}\right) \\
\end{array}$ & $\begin{array}{c}\text { Area to } \\
\text { volume ratio } \\
\left(\mathrm{m}^{2} / \mathrm{m}^{3}\right)\end{array}$ \\
\hline \multicolumn{4}{|l|}{ Hyper-Saline } \\
\hline Apodi & 3.90 & $17,489.01$ & 0.22 \\
\hline Conchas & 2.04 & $5,022.56$ & 0.41 \\
\hline Guamaré & 3.36 & $8,037.77$ & 0.42 \\
\hline Galinhos & 10.00 & $53,367.32$ & 0.19 \\
\hline \multicolumn{4}{|l|}{ Positive } \\
\hline Ceará-Mirim & 0.73 & $1,095.00$ & 0.66 \\
\hline Potengi & 18.14 & $35,151.96$ & 0.52 \\
\hline Nísia-Floresta & 3.55 & $3,750.00$ & 0.95 \\
\hline Papeba & 1.19 & 950.00 & 1.25 \\
\hline Guaraíra & 12.29 & $13,294.13$ & 1.01 \\
\hline
\end{tabular}

The Kruskal-Wallis (1952) statistic test applied to the estuaries comparison suggested a significant difference between the positive and hyper-saline classified estuaries. The positive Papeba, Guaraíra and Nísia-Floresta estuaries also presented difference when compared to the hypersaline estuaries. In a general way, the higher heavy metal concentrations were found in the hypersaline estuaries. These results can be a response of the higher pollutants loads to these areas. On the other hand, the hydrodynamic conditions can lead to the biggest potential for pollutants to accumulate. According to Largier et al. (1997), hyper-saline estuaries are usually characterized by weak tide dispersion capacity, resulting in longer water resident time along the estuarine bed. So, as a result, these ecosystems tend to accumulate contaminants rather than export them to neighbor systems (Blake et al. 2004). Another typical feature of these areas are the high evaporation rates, contributing to the concentration of solutes in the water column, inducing to coagulation and finally precipitation of insoluble authigenic minerals in surface sediment (Shumilin et al. 2002).
In the hypersaline environments precipitation dynamic, Soto-Jiménez and Páez-Osuna (2008) suggested that metals highly associated with sediment matrixes like organic matter, carbonates or oxides, represents an important fraction. According to Sindern et al. (2007), the predominantly fine grain sized sediments and high levels of organic matter turned the studied area a potential deposit for pollutants. However, it is not possible to observe in the present study, any significant correlation between organic matter and metals concentrations ( $r<0.35 ; \mathrm{p}<0.05)$. The low levels of organic matter did not influence the local heavy metal concentration. Results suggest that the heavy metal concentrations present in the studied area may be linked with another sediment matrix.

Although concentrations of some metals are higher in most hyper-saline estuaries (except for $\mathrm{Zn}$ ), these concentrations are below the natural background concentrations of metals in sediment (Table III). The shale is a sedimentary rock formed by silty-clay particles, being one of the most common sedimentary rocks on the planet. It is a rock that breaks easily and separates into thin layers along well developed planes very close to each other (Lutgens and Tarbuck 1989). It is well known that heavy metal concentrations is not homogeneously among the various particle fractions of sediment, were the finer fractions $(<$ $8 \mu \mathrm{m}$ ) retain the higher metal concentrations in relation to bulk sediments. Thus, it is necessary to consider that the extraction of metals in this study was done in the fraction less than $1 \mathrm{~mm}$ (composed of the primary mineral quartz), which is a poor adsorbent for metals. This fraction can be up to 4 times less than the concentration of metals present in the fraction smaller than $8 \mu \mathrm{m}$. In this way, we can consider worrying the concentrations potentially available in these estuaries, resulting from the anthropic activities.

The relatively low concentrations of the environment didn't exceed the values obtained 
TABLE III

Concentration in $\mu \mathrm{g} / \mathrm{g}$ of some metals in continental crust, shale and coastal sediments.

\begin{tabular}{|c|c|c|c|c|}
\hline Metal & Continental Crust $^{1}$ & Shale $^{2}$ & Coastal Sediments (background) ${ }^{3}$ & $\begin{array}{c}\text { Coastal Sediments } \\
\text { ("high" concentration) }\end{array}$ \\
\hline $\mathrm{Cd}$ & 0.1 & 0.3 & $0.1-0.6$ & 0.54 \\
\hline $\mathrm{Cr}$ & 126 & 90 & $50-100$ & 125 \\
\hline $\mathrm{Cu}$ & 25 & 45 & $10-50$ & 42 \\
\hline $\mathrm{Pb}$ & 14.8 & 20 & $5-30$ & 45 \\
\hline $\mathrm{Zn}$ & 65 & 95 & $1.2->100$ & 135 \\
\hline
\end{tabular}

${ }^{1}$ Wedepohl (1995); ${ }^{2}$ Mason and Moore (1982); ${ }^{3}$ NAVFAC (2000); ${ }^{4}$ Daskalakis and O'Connor (1995): The "high" concentration of the elements in sediments was defined as the geometric mean of the concentrations plus a standard deviation of the mean of the National Status and Trends.

in the other locations (Table I), with $\mathrm{Pb}$ and $\mathrm{Cr}$ concentrations similar to the Poxin and Mahanadi estuaries. The differences between the present study and the referenced literature can be explained taking into account the influence of fine grain size on the dynamics of accumulation of heavy metals (Maslennikova et al. 2012).

The Potengi estuary presented some of the higher heavy metals levels in the whole research. According to Souza and Ramos e Silva (2011) and Ramos e Silva et al. (2003, 2006), during the last decades, the Potengi estuary passed through intensive ecosystem degradation. The expansion of the cities of Natal, São Gonçalo do Amarante and Macaíba increased the loading from industrial and domestic wastewater into the estuary. Ramos e Silva et al. (2001) registered that concentrations in Crassostrea rhizophorae from the Potengi can be interpreted to be high on a global scale for $\mathrm{Zn}$ and $\mathrm{Cu}$, indicating atypically raised bioavailabilities. Emerenciano et al. (2009) studied heavy metals concentrations in the Anomalocardia brasiliana mussels living in the same area. The authors also found critical high concentrations of $\mathrm{Cr}, \mathrm{Zn}$ and $\mathrm{Pb}$. Silva et al. (2001) explained the high levels of heavy metal load as the result of dredging, fertilizers and pesticides use in agriculture and other anthropogenic activities, as well as domestic and industrial discharges that reach the Potengi river through the Baldo channel. Meantime,
Medeiros (2009) connected the higher heavy metals concentrations to the fine grain size sediment and the organic matter available in the area.

Lastly, the low Cd levels reached in all of the sampling sites of the present study agreed with the result obtained by Téodulo et al. (2003) and Passos (2010) in the sediment of Suape and Poxim estuaries, both of them in the Northeast region of Brazil. Still, according to Passos (2010), Cd is present only in the residual phase, inaccessible to the approach used in the present work. On the other hand, Sindern et al. (2007) concluded that in the Potengi estuary, close to wastewater outlets, a characteristic anthropogenic heavy metal signature is clear in enhanced $\mathrm{Cd}$ concentrations relative to reference elements such as $\mathrm{Al}$ and Fe. The same pattern occurred for other metals.

\section{CONCLUSIONS}

Nine estuaries of Rio Grande do Norte coast were evaluated for potentially mobile heavy metals concentrations, through the application of diluted hydrochloric acid ( $\mathrm{HCl})$. The potential heavy metal bioavailability results followed the descending order $\mathrm{Pb}<\mathrm{Zn}<\mathrm{Cr}<\mathrm{Cu}<\mathrm{Cd}$. None of the values exceeded the safe limits proposed by the available literature. On the other hand, some authors suggested that the tissues of some benthic organisms of Potengi river already contain levels above the secure concentrations, reinforcing the 
importance of the heavy metal bioavailability evaluation in the area.

The negative estuaries showed to be significantly more contaminated then the positive. Nevertheless, the obtained data did not permit the elucidation of the reasons for these differences. Thus, results obtained in the present research represent one more step in the heavy metal accumulation comprehension in the study site. Notwithstanding, more and different approaches must be applied for better understanding of the heavy metal cycling in the Rio Grande do Norte estuarine sites.

\section{REFERENCES}

AGEMIAN H AND CHAU ASY. 1976. Evaluation of extraction techniques for the determination of metals in aquatic sediments. Analyst 101: 761-767.

BEVILACQUA JE, SILVA IS, LICHTIG J AND MASINI JC. 2009. Extração seletiva de metais pesados em sedimentos de fundo do Rio Tietê, São Paulo. Quím Nova 32: 26-33.

BLAKE AC, CHADWICK DB, ZIRINO A AND RIVERADUARTE I. 2004. Spatial and temporal variations in copper speciation in San Diego Bay. Estuaries 27: 437447.

BYERS S, MILLS E AND STEWART P. 1978. Comparison of methods of determining organic carbon in marine sediments, with suggestions for a standard method. Hydrobio 58: 43-47.

COSTA DFS, ROCHA RM, CANDIDO GA AND SOARES AMVM. 2015. Geographical location and solar salt production. Mercator 14: 91-98.

DASKALAKIS KD AND O'CONNOR TP. 1995. Distribution of chemical concentrations in U.S. coastal and estuarine sediment. Mar Environ Res 40(4): 381-398.

DAVUTLUOGLU OI, SECKIN G, ERSU CB, YILMAZ T AND SARI B. 2011. Heavy metal content and distribution in surface sediments of the Seyhan River, Turkey. J Environ Manage 92: 2250-2259.

DINIZ MTM, FERREIRA AS AND MACÊDO DE MARIA GK. 2015. Análise integrada da paisagem e formas de uso do solo no litoral de Galinhos/RN: subsídios à gestão integrada da zona costeira. Cad Geogr 25: 49-69.

EMERENCIANO DP, SILVA HFO, CARVALHO GC, CRUZ, ÂMF AND MOURA MDFV. 2009. Análise da ocorrência de metais: bário, cádmio, chumbo, cobre, cromo, estanho, níquel e zinco, em mexilhão (Anomalocardia brasiliana) coletados no Estuário Potengi/Jundiaí-RN. Rev Publica 4: $1-9$.
FANG T, LI X AND ZHANG G. 2005. Acid volatile sulfide and simultaneously extracted metals in the sediment cores of the Pearl River Estuary, South China. Ecotox Environ Safe 61: 420-431.

FÖLDI C, DOHRMANN R, MATERN K AND MANSFELDT T. 2013. Characterization of chromium-containing wastes and soils affected by the production of chromium tanning agents. J Soil Sedim 13: 1170-1179.

FÖRSTNER U AND KERSTEN M. 1989. Assessment of metal mobility in dredged material and mine waste by pore water chemistry and solid speciation. Chemistry and biology of solid waste, Springer Berlin Heidelberg, p. 214 237.

HANG X, WANG H, ZHOU J, DU C AND CHEN X. 2009. Characteristics and accumulation of heavy metals in sediments originated from an electroplating plant. J Hard Mater 163: 922-930.

HOSSEINI SV, AFLAKI F, SOBHANARDAKANI S, TAYEBI L, BABAKHANI LA AND REGENSTEIN JM. 2013. Analysis of mercury, selenium and tin concentrations in canned fish marketed in Iran. Environ Monit Assess 85: 6407-6412.

KIBRIA G, HOSSAIN MM, MALLIK D, LAU TC AND WU R. 2016. Monitoring of metal pollution in waterways across Bangladesh and ecological and public health implications of pollution. Chemosphere 165:1-9.

KIBRIA G, LAU TC AND WU R. 2012. Innovative 'Artificial Mussels' Technology for Assessing Spatial and Temporal Distribution of Metals in Goulburn-Murray Catchments Waterways, Victoria, Australia: Effects of Climate Variability (dry vs.wet years). Environ Inter 50: 38-46.

KOMINAR RJ. 2002. Bioavailable Heavy Metal Sediment Loading In Laurel Creek. Department of Chemistry, Wilfrid Laurier University, Waterloo, ON.

KRUSKAL WH AND WALLIS WA. 1952. Use of ranks in one-criterion variance analysis. J Am Stat Assos 47: 583621.

KUMAR R, ALAMELU D, ACHARYA R AND RAI AK. 2014. Determination of concentrations of chromium and other elements in soil and plant samples from leather tanning area by Instrumental Neutron Activation Analysis. J Radioanal Nuc Chem 300: 213-218.

LACERDA LD, VAISMAN AG, MAIA LP, RAMOS E SILVA CA AND CUNHA EMS. 2006. Relative importance of nitrogen and phosphorus emissions from shrimp farming and other anthropogenic sources for six estuaries along the NE Brazilian coast. Aquaculture 253: 433-446.

LARGIER JL, HOLLIBAUGH J AND SMITH S. 1997. Seasonally hypersaline estuaries in Mediterranean-climate regions. Estuar Coast Shelf S 45: 789-798.

LI LY, HALL K, YUAN Y, MATTU G, MCCALLUM D AND CHEN M. 2009. Mobility and bioavailability of trace metals in the water-sediment system of the highly 
urbanized Brunette watershed. Water Air Soil Poll 197: 249-266.

LUTGENS FK AND TARBUCK EJ. 1989. The atmosphere: an introduction to Meteorology. Prentice Hall.

MASLENNIKOVA S, LARINA N AND LARIN S. 2012. The Effect of Sediment Grain Size on Heavy Metal Content. Lakes, Reservoirs and Ponds 6: 43-54.

MASON B AND MOORE CB. 1982. Principles of Geochemistry. J Wiley \& Sons, New York, 344 p.

MEDEIROS RLDS. 2009. Avaliação das condições química e física dos sedimentos do estuário Jundiaí-Potengi. Dissertação (Mestrado) - Programa de Pós-Graduação em Química. Universidade Federal do Rio Grande do Norte, 105 p. (Unpublished).

MOALLA SMN. 1997. Physical fractionation of trace and rare Earth elements in the sediments of Lake Nasser. Talanta 45: 213-221.

MUTLU MM, CRUDU M, MAIER SS, DESELNICU D, ALBU L, GULUMSER G, BITLISLI B, BASARAN OB, TOSUN CC AND ADIGUZEL ZENGIN AC. 2014. Ecoleather: Properties of Chromium-free Leathers Produced with Titanium tanning Materials obtained from the Wastes of the metal Industry. Ekoloji 23: 83-90.

NAVFAC. 2000. Guide for incorporating bioavailability adjustments into human health and ecological risk assessments at U. S. Navy and Marine Corps Facilities Part 1: overview of metals bioavailability. Naval Facilities Engineering Service Center, User's Guide UG-2041-ENV, Washington, DC.

OKORO HK, FATOKI OS, ADEKOLA FA, XIMBA BJ AND SNYMAN RG. 2012. A review of sequential extraction procedures for heavy metals speciation in soil and sediments. J Environ Anal Tox 1: 1-9.

PASSOS EA, ALVES JC, DOS SANTOS IS, JOSE DO PATROCÍNIO HA, GARCIA CAB AND COSTA ACS. 2010. Assessment of trace metals contamination in estuarine sediments using a sequential extraction technique and principal component analysis. Microchem J 96: 50-57.

PASSOS EA, ALVES JPH, GARCIA CAB AND COSTAACS. 2011. Metal Fractionation in Sediments of the Sergipe River, Northeast, Brazil. J Brazil Chem Soc 22: 828-835.

RAMOS E SILVA CA, DAVALOS P, STERNBERG LSL, SOUZA FES, SPYRIDES MHC AND LUCIO PS. 2010. The influence of shrimp farms organic waste management on chemical water quality. Est Coast Shelf Sci 90:55-60.

RAMOS E SILVA CA, MIRANDA LB, DÁVALOS PB AND DA SILVA MP. 2003. Hydrochemistry in tropical hypersaline and positive estuaries. Pan-American J Aquat Sci 5: 432-443.

RAMOS E SILVA CA, RAINBOW PS, SMITH BD AND SANTOS ZL. 2001. Biomonitoring of trace metal contamination in the Potengi Estuary, Natal (Brazil), using the oyster Crassostrea rhizophorae, a local food source. Water Res 35: 4072-4078.

RAMOS E SILVA CA, SILVA AP AND OLIVEIRA SR. 2006 Concentration, stock and transport rate Concentration, stock and transport rate of heavy metals in a tropical red mangrove, Natal, Brazil. Mar Chem 99: 2-11.

RELIC D, DORDEVIC D, POPOVIC A, JADRANIN M AND POLIC P. 2010. Fractionation and potential mobility of trace metals in Danube alluvial aquifer within an industrialized zone. Environ Monit Assess 171: 229-248.

SALOMONS W AND STIGLIANI W. 1995. Biogeodynamics of Pollutants in Soils and Sediments. Berlin: Springer Verlag, $352 \mathrm{p}$.

SCHNEIDER IL, TEIXEIRA EC, RODRIGUES MLK AND ROLIM S. 2014. Metal content and distribution in surface sediments in an industrial region. An Acad Bras Cienc 86: 1043-1061.

SHUMILIN E, GRAJEDA-MUNÕZ M, SILVERBERG N AND SAPOZHNIKOV D. 2002. Observations on trace element hypersaline geochemistry in surficial deposits of evaporation ponds of Exportadora de Sal, Guerrero Negro, Baja California Sur, México. Mar Chem 79: 133-153.

SINDERN S, LIMA RFS, SCHWARZBAUER J AND PETTA RA. 2007. Anthropogenic heavy metal signatures for the fast growing urban area of Natal (NE-Brazil). Environ Geol 52: 731-737.

SINGH R, GAUTAM N, MISHRA A AND GUPTA R. 2011. Heavy metals and living systems: An overview. Indian J Pharmaco 43: 246-253.

SKORDAS K, KELEPERTZIS E, KOSMIDIS D, PANAGIOTAKI P AND VAFIDIS D. 2015. Assessment of nutrients and heavy metals in the surface sediments of the artificially lake water reservoir Karla, Thessaly, Greece. Environ Earth Sci 73: 4483-4493.

SOTO-JIMÉNEZ MF AND PÁEZ-OSUNA F. 2008. Diagenetic processes on metals in hypersaline mudflat sediments from a subtropical saltmarsh (SE Gulf of California): postdepositional mobility and geochemical fractions. Appl Geochem 23: 1202-1217.

SOUZA FES AND RAMOS E SILVA CA. 2011. Ecological and economic valuation of the Potengi estuary mangrove wetlands (NE, Brazil) using ancillary spatial data. J Coas Conserv 15: 195-206.

SUNDARAY SK, NAYAK BB, LIN S AND BHATTA D. 2011. Geochemical speciation and risk assessment of heavy metals in the river estuarine sediments - a case study: Mahanadi basin, India. J Hard Mater 186: $1837-$ 1846.

SUTHERLAND RA. 2002. Comparison between non-residual $\mathrm{Al}, \mathrm{Co}, \mathrm{Cu}, \mathrm{Fe}, \mathrm{Mn}, \mathrm{Ni}, \mathrm{Pb}$ and $\mathrm{Zn}$ released by a three-step sequential extraction procedure and a dilute hydrochloric acid leach for soil and road deposited sediment. Appl Geochem 17: 353-365. 
SUTHERLAND RA AND TACK FMG. 2008. Extraction of labile metals from solid media by dilute hydrochloric acid. Environ Monit Assess 138: 119-130.

TEÓDULO MJR, LIMA ES, NEUMANN VHML, LEITE PRB AND SANTOS MRL. 2003. Comparação de métodos de extração parcial de metais traço em solos e sedimentos de um estuário tropical sob a influência de um complexo industrial portuário, Pernambuco, Brasil. Estud Geol 13: 23-34.

TESTA SM, GUERTIN J, JACOBS JA AND AVAKIAN CP. 2004. Sources of chromium contamination in soil and groundwater, CRC Press: Boca Raton, FL, p. 143-164.
VAALGAMAA S. 2004. The effect of urbanization on Laajalahti Bay, Helsinki City, as reflected by sediment geochemistry. Mar Poll Bull 48: 650-662.

WEDEPOHL KH. 1995. The composition of the continental crust. Geochim Cosmochim Acta 59(7): 1217-1232.

ZHONG XL, ZHOU SL, ZHU Q AND ZHAO QG. 2011. Fraction distribution and bioavailability of soil heavy metals in the Yangtze River Delta-a case study of Kunshan City in Jiangsu Province, China. J Hard Mater 30: 13-21. 